\title{
Digestibility of diets and nutritional value of torula yeast (Candida utilis) for rabbits (Oryctolagus cuniculus) and agoutis (Dasyprocta spp.)
}

\section{Digestibilidade das dietas e valor nutricional da levedura torula (Candida utilis) para coelhos (Oryctolagus cuniculus) e cutias (Dasyprocta spp.)}

\author{
Fábio Morais Hosken ${ }^{1 *}$; Walter Motta Ferreira ${ }^{2}$; Felipe Norberto Alves Ferreira ${ }^{3}$; \\ Clarice Speridião Silva Neta ${ }^{4}$; Katiuscia Cristina das Neves Mota ${ }^{4}$; \\ Abel Ortiz Milán ${ }^{5}$
}

\begin{abstract}
The aim of this study was to assess the nutritional value of diets that contain torula yeast in rabbits and agoutis and the influence of torula yeast on the apparent digestibility of the nutrients. In the first experiment, $32 \mathrm{New}$ Zealand White rabbits were fed diets with four different levels $(0 \%, 5 \%, 10 \%$, and $15 \%$ ) of torula yeast that was substituted for soybean meal. The experimental design was completely randomized with four treatments and eight repetitions. The digestibility coefficients (DC) of dry matter (DM; DCDM), crude protein (DCCP), neutral detergent fiber (DDNDF), ether extract (DCEE), and gross energy (DCGE), as well as the mean daily consumption (MDC), were calculated (MDC: 113.98, 113.96, 113.22, and $115.07 \mathrm{~g} \mathrm{animal}^{-1}$; DCDM: 71.04\%, 69.98\%, 67.79\%, and 74.08\%; DCCP: $80.17 \%$, $79.55 \%, 75.10 \%$, and $78.47 \%$; DCND: $66.85 \%, 65.50 \%, 63.31 \%$, and $70.12 \%$; DCEE: $77.83 \%$, $76.46 \%, 78.36 \%$, and $82.07 \%$; and DCGE: $71.04 \%, 69.98 \%, 68.37 \%$, and $73.82 \%$ ). No significant effects $(\mathrm{P}>0.05)$ were found on the MDC or the DCs for the different yeast levels, and the inclusion of torula up to $15 \%$ did not affect diet digestibility. The digestible energy (DE) ( $\left.\mathrm{kcal} \mathrm{kg}^{-1} \mathrm{DM}^{-1}\right)$ of a diet with $15 \%$ torula yeast was calculated as 2,870.52 with the methodology proposed by Matterson (MMT) and 2,870.89 when corrected by the methodology proposed by Villamide (MVD). Linear regression estimated the DE $\left(\mathrm{kcal} \mathrm{kg}^{-1} \mathrm{DM}^{-1}\right)$ as 2,805.22. The digestible protein (DP; $\mathrm{g} \mathrm{kg}^{-1} \mathrm{DM}^{-1}$ ) of a diet with $15 \%$ torula yeast was calculated as 182.6 with the MTT method and 190.9 with the MVD correction. Linear regression estimated the DP $\left(\mathrm{g} \mathrm{kg}^{-1} \mathrm{DM}^{-1}\right)$ as 293.0. In the second experiment, 20 agoutis were divided into two treatment groups: a control group and one given a base diet containing $30 \%$ torula yeast. The experimental design was completely randomized with two treatments and ten replications. The DCDM, DCCP, DCNDF, DCEE, DCGE, and the DCs of organic matter (DCOM) and mineral matter (DCMM), as well as the MDC, were calculated (MDC: 84.48 and $90.48 \mathrm{~g}^{\text {animal }}{ }^{-1}$, DCDM: $67.62 \%$ and $67.06 \%$, DCCP: $71.12 \%$ and $68.19 \%$, DCNDF: $72.70 \%$ and $69.89 \%$, DCOM: $70.52 \%$ and 20.27\%, and DCMM: $36.27 \%$ and 33.16\%), and no significant differences $(\mathrm{P}>0.05)$ were found. The
\end{abstract}

\footnotetext{
${ }^{1}$ Dicente de Doutorado em Zootecnia, Escola de Veterinária, Universidade Federal de Minas Gerais, UFMG, Belo Horizonte, MG, Brasil. E-mail: planetarural@terra.com.br

2 Prof. Titular, Dept ${ }^{\circ}$ de Zootecnia, UFMG, Belo Horizonte, MG, Brasil. E-mail: waltermf@ufmg.br

${ }^{3}$ Dicente de Doutorado em Zootecnia, UFMG, Belo Horizonte, MG, Brasil. E-mail: felipe.norberto@yahoo.com.br

${ }^{4}$ Discentes de Mestrado em Zootecnia, UFMG, Belo Horizonte, MG, Brasil. E-mail: clarice.zootecnia@yahoo.com.br; katiusciazootecnia@hotmail.com

${ }_{5}^{5}$ Prof. Titular, Centro para Estudos em Tecnologia Agrícola, Universidade de Guantanamo, CUG, Guantanamo, Cuba. E-mail: abel@cug.co.cu

* Author for correspondence
} 
DCEE $(63.39 \%$ and $48.04 \%)$ and DCGE $(68.00 \%$ and $63.73 \%)$ results differed significantly $(\mathrm{P}<0.05)$. The DE $\left(\mathrm{kcal} \mathrm{kg}^{-1} \mathrm{DM}^{-1}\right)$ of $30 \%$ torula yeast in the diet was calculated as $1,714.22$ with the MMT method and 1,663.69 with the MVD correction. The DP $\left(\mathrm{g} \mathrm{kg}^{-1} \mathrm{DM}^{-1}\right)$ of $30 \%$ torula yeast in the diet was calculated as 259.1 with the MMT method and 263.2 with the MVD correction.

Key words: Feed, rabbit, yeast, nutrition, nutrient

\section{Resumo}

Objetivou-se a avaliação nutricional das dietas com a inclusão de levedura torula para coelhos e cutias e sua influência sobre a digestibilidade aparente dos nutrientes. No primeiro experimento, utilizou-se 32 coelhos Nova Zelândia Branco. Avaliou-se quatro níveis de inclusão (0, 5, 10 e 15 \%) de torula em substituição ao farelo de soja. O delineamento empregado foi inteiramente casualizado, com quatro tratamentos e oito repetições. Determinaram-se os coeficientes de digestibilidade (CD) da matéria seca (CDMS), da proteína bruta (CDPB), da fibra detergente neutro (CDFDN), do extrato etéreo (CDEE) e da energia bruta (CDEB) das dietas, bem como os valores de energia e proteína digestíveis da torula. Foram obtidos os valores de digestibilidade para CDMS (71,04; 69,98; 67,79 e 74,08 \%), CDPB (80,17; 79,$55 ; 75,10$ e 78,47 \%), CDFDN (66,85; 65,50; 63,31 e 70,12 \%), CDEE $(77,83 ; 76,46 ; 78,36$ e 82,07 \%) e CDEB (71,04; 69,98; 68,37 e 73,82 \%), respectivamente. Não houve efeito significativo ( $P>0,05)$ para os CD estudados nos níveis de inclusão da levedura torula nas dietas. Os valores de ED (kcal. $\mathrm{kg}^{-1}$ ) da torula foi de 2870,52 utilizando-se a metodologia proposta por Matterson (MMT) com 15\% de inclusão do alimento e, 2870,89 quando corrigido pela matéria seca do alimento teste conforme Villamide (MVD). O valor estimado da ED ( $\mathrm{kcal}^{\mathrm{kg}} \mathrm{kg}^{-1}$ ) por regressão linear foi de 2805,22 . Os valores de PD (g. $\mathrm{kg}^{-1} \mathrm{MS}$ ) da torula foram de 182,6 utilizando-se a metodologia MMT com $15 \%$ de inclusão, e 190,9 utilizando-se a correção de cálculo de MVD. O valor estimado da PD (g.kg-1 MS) por regressão linear foi de 293,0. No segundo experimento, utilizou-se 20 cutias, distribuídas em dois tratamentos, uma dieta base e outra com inclusão de $30 \%$ de torula sobre a dieta base. O delineamento empregado foi inteiramente casualizado, com dois tratamentos e dez repetições. Neste ensaio se determinou o CDMS, CDPB, CDFDN, CDEE, CDEB e os CD da matéria orgânica (CDMO) e matéria mineral (CDMM), bem como o CMD. Foram obtidos os resultados para CMD (84,48 e 90,48 g. animal $\left.{ }^{-1}\right)$, CDMS (67,62 e 67,06 $\%), \operatorname{CDPB}(71,12$ e $68,19 \%), \operatorname{CDFDN}(72,70$ e $69,89 \%), \operatorname{CDMM}(36,27$ e $33,16 \%)$ e CDMO $(70,52$ e 70,27\%), e que submetidos a análise estatística não apresentaram diferença significativa $(P>0,05)$. Os resultados para CDEE $(63,39$ e 48,04 \%) e CDEB (68,00 e 63,73\%) diferiram significativamente $(\mathrm{P}<0,05)$. Os valores de ED $\left(\mathrm{kcal}_{\mathrm{kg}}{ }^{-1}\right)$ da torula para cutias foram de 1714,22, quando utilizada MMT, e de 1663,69, quando utilizada MVD. Os valores de PD ( g.kg $\left.^{-1} \mathrm{MS}\right)$ da torula foram de 259,1, quando utilizada MMT e de 263,2, quando utilizada MVD.

Palavras-chave: Alimento, cunicultura, levedura, nutrição, nutriente

\section{Introduction}

Cuniculture is the inexpensive practice of raising rabbits by targeting productivity, shorter production cycles, and animal prolificacy. Because of the digestive characteristics of rabbits, it is possible to use nonconventional foods in their diet. Despite the existing cultural barrier in Brazil regarding the consumption of rabbit meat, these attitudes might be changed by publicizing information on the nutritional quality of the meat, and this would allow the cuniculture exploitation of the meat, which can contribute to food safety and better nutrition in the population.

The agouti is a wild rodent mammal that lives in woods and barns and feeds on roots, fruits, and seeds from trees. It belongs to the Rodentia order and the Dasiproctidae family, and its scientific name is Dasyprocta spp. It is a large rodent with a body length between 49 and $64 \mathrm{~cm}$. This animal has been commercially bred in several states in Brazil due to the high quality of its meat. It is the species of Brazilian wildlife with the highest zootechnical 
potential. The rational use of wildlife in order to maintain and develop animal populations that can be used for the consumption of diets with highquality protein is very important for humans (LUI et al., 2008).

Previous studies on the agouti, especially those concerning the anatomical and physiological characteristics of their digestive tract, are rare. Garcia et al. (2000) has shown that this species of wild rodent has a long small intestine, which measures an average of more than $7 \mathrm{~m}$ in length. The colon and rectum together measure approximately 1 $\mathrm{m}$ and $17 \mathrm{~cm}$, and the cecum is long and sacculated.

Modern animal production has become increasingly complex due to changing feeding patterns (EULER, 2009). For production, nutrition is fundamental. For the nutritional assessment of a diet, it is necessary to know the amounts of nutrients and energy that are present and that will be used by the animal, and this information is obtained through digestibility trials (COELHO et al., 2008b). These trials have become a useful tool in the assessments of foods or diets because the nutritional value of food is directly related to the digestibility of its nutritive principles. The digestibility assays for rabbits were improved and standardized in the 1990s (PÉREZ et al., 1995) because of the expanding research on cuniculture in Europe. Other studies that assess the digestibility of nutrients in alternative foods have been performed (ARRUDA et al., 2005).

Torula is an alternative protein source, and its raw material, vinasse, is not used in human nutrition. It is important to study foods that do not compete with the human diet, as this is a constant criticism of international agencies (BUTOLO, 2002). Food substitutes for soy and corn are extremely important for reducing costs and for the diversification of nutritional strategies, and these substitutes are very relevant due to the high seasonal prices of commodities, which are very susceptible to changes in the international market (NOGUEIRA, 2007).
The torula yeast is obtained through an aerobic fermentation process that uses vinasse as a substrate for the propagation of fodder yeast, and this process was developed by the Instituto Cubano de Investigaciones de los Derivados de la Caña de Azúcar (ICIDCA) (in English: Cuban Institute for Research on Sugarcane Derivatives) in the 1970s. This process is currently implemented in a systematic way in three Cuban factories that produce 5,000 tons/year [see Table 1 from RODRÍGUEZ et al. (2011) of the composition of the Cuban industrial torula]. This level of production has allowed the development of a protein core for fattening pigs and other domestic animals.

Table 1. Chemical composition of the torula yeast that was produced from vinasse from an alcohol distillery (in $\%$ of dry matter) for dry matter (DM), organic matter $(\mathrm{OM})$, crude protein $(\mathrm{CP})$, gross energy (GE), crude fiber $(\mathrm{CF})$, calcium $(\mathrm{Ca})$, total phosphorus $(\mathrm{P})$, lysine, and methionine + cystine.

\begin{tabular}{lc}
\hline \multicolumn{1}{c}{ Indicators \% DM } & Yeast grown on vinasse \\
\hline $\mathrm{DM}$ & 91.05 \\
$\mathrm{OM}$ & 92.85 \\
$\mathrm{CP}(\mathrm{N} \times 6.25)$ & 43.24 \\
$\mathrm{GE}, \mathrm{kcal} \mathrm{kg}^{-1}$ & 3.981 \\
$\mathrm{CF}$ & 1.60 \\
$\mathrm{Ca}$ & 0.93 \\
$\mathrm{P}$ & 1.61 \\
Lysine & 4.5 \\
Methionine + cystine & 1.7 \\
\hline
\end{tabular}

Rodríguez et al. (2011).

Among the microorganisms that can be used in diets, the use of the Candida utilis species has proven favorable due to its capacity to assimilate hexose and pentose and other nonsugar organic compounds, such as acids, alcohols, and aldehydes. The industrial process that produces dried torula begins with the autolysis of the yeast suspension that is retained in distilleries through centrifugation, which yields a supernatant that is ultrafiltrated and dried by evaporation. The yeast propagation process 
results in a reduction in the contaminant load from vinasses from $70-80 \mathrm{~kg} / \mathrm{m}^{3}$ to $10-15 \mathrm{~kg} / \mathrm{m}^{3}$. At the same time, almost a ton of yeast is obtained per 60 $\mathrm{m}^{3}$ of vinasse that is used in the process.

Nutritionally, yeasts are considered important sources of protein, vitamins, and minerals. This protein source contains $35 \%-45 \%$ crude protein (PILOTO; MACÍAS, 2005), and, as shown in Table 2 , it is noteworthy for its lysine content, which far exceeds that of soybean meal. Similarly, Rodríguez et al. (2011) examined the minerals in torula yeast that was produced from distillery vinasse by analyzing neutron activation. Potassium (K), calcium $(\mathrm{Ca})$, chlorine $(\mathrm{Cl})$, magnesium $(\mathrm{Mg})$, iron $(\mathrm{Fe})$, and sodium $(\mathrm{Na})$ were present in the highest concentrations, along with a high content of mineral matter $(7.15 \%)$ and total phosphorus $(\mathrm{P} ; 1.61 \%)$. The mineral composition of torula yeast from vinasse exhibits values that are higher than those reported by the National Research Council (1998) for soybean meal.

Table 2. Contents of essential amino acids of vinasse yeast and soybean meal.

\begin{tabular}{lcc}
\hline \multicolumn{1}{c}{ Amino acids } & $\begin{array}{c}\text { Vinasse } \\
\text { yeast }\end{array}$ & $\begin{array}{c}\text { Soybean } \\
\text { meal }\end{array}$ \\
\hline Arginine & 2.04 & 3.45 \\
Histidine & 1.71 & 1.41 \\
Isoleucine & 1.95 & 1.98 \\
Leucine & 3.90 & 3.29 \\
Lysine & 4.07 & 2.90 \\
Methionine + cystine & 1.08 & 1.15 \\
Phenylalanine + tyrosine & 3.24 & 3.63 \\
Treonine & 2.19 & 1.71 \\
Tryptophan & 1.07 & 0.90 \\
Valine & 2.29 & 2.15 \\
\hline
\end{tabular}

Adapted from Saura et al. (2008).

Previous studies of torula, which is still not produced in Brazil despite its potential, are scarce.
Therefore, the aim of this study was to determine and compare the digestibility, levels of digestible protein, and energy values of diets that include torula in rabbits and agoutis.

\section{Materials and Methods}

\section{Experimental protocol for rabbits}

For the in vivo digestibility trial in growing rabbits, thirty-two 65-day-old New Zealand White rabbits were housed in galvanized wire cages that were equipped with semiautomatic feeders, nipple drinkers, and feces collectors in the bottom of the cages.

A base diet (BD) was tested along with three other formulated diets that contained $5 \%, 10 \%$, or $15 \%$ torula yeast relative to the macroingredients in the BD. The microingredients were maintained at the same quantities as those in the BD. The diets were formulated as recommended by De Blas and Mateos (2010), and they were isoproteic and isocaloric. The diets were offered ad libitum. Table 3 shows the ingredients in each treatment and the analyzed values of the diets. Table 4 shows the composition of the torula, which was the same in all of the experiments that were conducted in this study.

The animals were allowed to adapt to their cages and diets for seven days, which was followed by a collection period of four days in total, during which individual food consumption and fecal production were measured and daily measurements of the quantities of food provided and the remains in the feeder were performed. Cecotrophy was not prevented, and any cecotropes that were found in the trays were weighed and incorporated into the hard feces for analysis. Contamination of the feces by feed was avoided by removing it and subtracting it from the ingested food. 
Table 3. Ingredients used in each treatment and values analyzed in the diets $\left(\mathrm{g} \mathrm{kg}^{-1} \mathrm{DM}^{-1}\right)$ for growing rabbits.

\begin{tabular}{lcccc}
\hline & \multicolumn{3}{c}{ Percentage of torula yeast (\%) } \\
\cline { 2 - 5 } Diet & 0 & 5 & 10 & 15 \\
\hline Alfalfa hay & 321.0 & 321.0 & 321.0 & 321.0 \\
Wheat bran & 250.0 & 250.0 & 250.0 & 250.0 \\
DCSC $^{1}$ & 150.0 & 150.0 & 150.0 & 150.0 \\
Soybean meal & 150.0 & 100.0 & 50.0 & 0.00 \\
Torula yeast & 0.00 & 50.0 & 100.0 & 150.0 \\
Corn & 77.0 & 77.0 & 77.0 & 77.0 \\
Soybean oil & 20.0 & 20.0 & 20.0 & 20.0 \\
Cane molasses & 20.0 & 20.0 & 20.0 & 20.0 \\
Common salt & 5.0 & 5.0 & 5.0 & 5.0 \\
Premix & 5.0 & 5.0 & 5.0 \\
Dicalcium phosphate & 1.1 & 1.1 & 1.1 & 1.1 \\
DL methionine & 0.9 & 0.9 & 0.9 & 0.9 \\
\hline Nutritive Principle & & & 891.1 & 897.1 \\
DM & 897.1 & 900.2 & 175.3 & 50.6 \\
CP & 186.2 & 186.4 & 46.8 & 305.0 \\
EE & 46.2 & 41.2 & 348.0 & 127.0 \\
NDF & 339.1 & 373.1 & 150.8 & 70.8 \\
ADF & 145.1 & 155.1 & 82.0 & 9.3 \\
Ashes & 78.8 & 70.3 & 15.2 & 6.1 \\
Ca & 11.7 & 8.9 & 6.6 & $4,062.80$ \\
P & 6.9 & 6.8 & $4,038.05$ & \\
GE, kcal kg-1 & $4,027.49$ & $4,048.82$ & & \\
\hline
\end{tabular}

The diets were formulated according to the requirements for growing rabbits proposed by De Blas and Mateos (2010).

${ }^{1}$ Disintegrated corn with its straw and corncob

$\mathrm{NDF}$, neutral detergent fiber; ADF, acidic detergent fiber.

Table 4. Chemical composition in the torula yeast $\left(\mathrm{g} \mathrm{kg}^{-1}\right.$ DM) used in both experiments.

\begin{tabular}{cc}
\hline Nutritive Principle & Analyzed value \\
\hline DM & 858.8 \\
CP & 366.2 \\
EE & 44.2 \\
OM & 787.3 \\
Ashes & 71.5 \\
NDF & 12.6 \\
ADF & 5.5 \\
Ca & 5.6 \\
P & 28.2 \\
GE, kcal kg-1 & 3970.80 \\
\hline
\end{tabular}

The feces were collected in plastic bags in the morning. Any hair in the bag was removed, and the bag was stored in a freezer at $-10^{\circ} \mathrm{C}$ until the end of the collection period. Subsequently, the feces were sent to the Animal Nutrition Laboratory of the Department of Zootechnics of the Federal University of Minas Gerais (UFMG), where the feces were cooled, homogenized, weighed, and dried in forced ventilation ovens at $55^{\circ} \mathrm{C}$ for $72 \mathrm{~h}$ in order to promote predrying. The weights of the air-dried samples were then determined. Once they were dried, the samples were ground in a knife-type mill with a $1-\mathrm{mm}$ sieve and then stored in plastic bottles until further analysis.

The experimental design was completely randomized with four treatments and eight animals per treatment, and each experimental unit consisted 
of one housed animal.

\section{Experimental protocol for agoutis}

This experiment was conducted at the Fazenda Zoo, which is located in the municipality of Paraopeba in the state of Minas Gerais, Brazil, where the commercial breeding of agoutis is authorized by the Instituto Brasileiro do Meio Ambiente e dos Recursos Naturais Renováveis (IBAMA) (in English: Brazilian Institute of Environment and Renewable Natural Resources)/Minas Gerais in accordance with current legislation.

Twenty agoutis (8 males, 12 females) with a mean initial weight of $2.9 \mathrm{~kg}$ were used. The animals were kept in galvanized wire cages that were suspended for a period of 16 days. All of the animals were adults with ages between 14 and 34 months. The cages measured $60 \mathrm{~cm}$ in length, 60 $\mathrm{cm}$ in width, and $40 \mathrm{~cm}$ in height, and they were equipped with semiautomatic feeders, nipple drinkers, and feces collectors at the bottom of the cages.

For this experiment, a BD was tested and formulated according to the recommendations of De Blas and Mateos (2010) for captive rabbits because no specific nutritional recommendations were found for agoutis. The test diet (TD) was formulated with $30 \%$ torula yeast added to the BD (Tables 5 and 6). The diets were in pellets that were $12-15 \mathrm{~mm}$ in length and $4-5 \mathrm{~mm}$ in diameter.

Table 5. Ingredients in the base diet $\left(\mathrm{g} \mathrm{kg}^{-1} \mathrm{DM}^{-1}\right)$ and in the diet with $30 \%$ torula yeast for mature agoutis.

\begin{tabular}{|c|c|c|}
\hline Ingredient & Base diet & Diet with $30 \%$ torula \\
\hline Alfalfa hay & 381.23 & 266.86 \\
\hline Wheat bran & 250.00 & 175.00 \\
\hline Soybean meal & 80.00 & 56.00 \\
\hline Corn & 80.84 & 56.60 \\
\hline $\mathrm{DCSC}^{1}$ & 150.00 & 105.00 \\
\hline Torula & 00.00 & 300.00 \\
\hline Molasses powder & 20.00 & 14.00 \\
\hline Dicalcium phosphate & 14.78 & 10.34 \\
\hline DL-Methionine & 1.29 & 0.90 \\
\hline L-Lysine & 3.86 & 2.70 \\
\hline Premix $^{2}$ & 3.00 & 2.10 \\
\hline Soybean oil & 10.00 & 7.00 \\
\hline White salt & 5.00 & 3.50 \\
\hline
\end{tabular}

${ }^{1}$ Disintegrated corn with its straw and corncob.

${ }^{2}$ Composition per kg of product: Vit. A, 1,200,000 UI; Vit $\mathrm{D}_{3}, 100,000 \mathrm{UI}$; Vit. E, 1,200 mg; Vit. B, 392 mg; Vit. B 2 , 360 mg; Pantothenic Acid, 2,900 mg; Vit. B ${ }_{12}, 0.06 \mu \mathrm{g}$; Vit. B, 3,920 mg; Antioxidant (BHT), 6,000 mg; Zinc, 7.8 g; Manganese, 8.81 g; Iron, $3 \mathrm{~g}$; Copper, $0.25 \mathrm{~g}$; Cobalt, $0.04 \mathrm{~g}$; Iodine, $0.012 \mathrm{~g}$. 
Table 6. Chemical composition analyzed $\left(\mathrm{g} \mathrm{kg}^{-1} \mathrm{DM}^{-1}\right)$ in diets for mature agoutis.

\begin{tabular}{lcc}
\hline \multirow{2}{*}{ Nutritive principle } & \multicolumn{2}{c}{$\mathrm{g} \mathrm{kg}^{-1} \mathrm{DM}$} \\
\cline { 2 - 3 } & Basic diet (BD) & Diet with torula (DT) \\
\hline $\mathrm{DM}$ & 903.4 & 889.7 \\
$\mathrm{CP}$ & 184.7 & 234.2 \\
$\mathrm{EE}$ & 55.9 & 43.9 \\
$\mathrm{NDF}$ & 346.1 & 281.1 \\
$\mathrm{ADF}$ & 130.8 & 103.0 \\
$\mathrm{Ashes}$ & 76.7 & 77.0 \\
$\mathrm{Ca}$ & 8.9 & 8.0 \\
$\mathrm{P}$ & 6.8 & 5.3 \\
$\mathrm{GE}, \mathrm{kcal} \mathrm{kg}{ }^{-1}$ & $4,128.13$ & $3,754.32$ \\
\hline
\end{tabular}

The animals were allowed to adapt to their cages and diets according to the following protocol as no information was found in the literature on maintaining agoutis in individual cages with pelleted diets. This step was performed in the original enclosures where the animals were bred. The experiment began with a phase of adaptation of the animals to the new diet, which was pelleted feed for rabbits. This phase lasted 48 days, with a transition period of 18 days that included the gradual introduction of the feed until the animals consumed $100 \%$ pelleted feed in their diet. This period was necessary because these animals had previously consumed a diet that was based on corn grains and supplements, such as tubers, fruits, and legumes, and they had never eaten pelleted food. Once the feed was accepted, the animals proceeded to the second phase, which involved their adaptation to a new caged environment for eight days. It was considered necessary to maintain the animals in group pens with 10 - to $20-\mathrm{m}^{2}$ wooden pickets, a natural substrate, holes, and wooden shelters on the ground, and this was a semi-intensive system. At the beginning of this phase, the 20 animals were separated in the enclosure, weighed, and identified, and, immediately after this handling, they were transferred to individual cages where they were kept under constant monitoring in case the animals did not tolerate the confinement or experienced problems from this change. This transition period lasted until the behavioral and physiological changes that were induced by the confinement decreased and their functions were stabilized. The third phase was the period of adaptation to the experimental diets, which lasted four days and which were administered ad libitum.

After this period of adaptation to the new food and environment, the data were collected for four days. During this period, the feces and leftover feed were weighed daily and replenished, and the samples were collected, identified, and stored. For this, a nylon-mesh screen was installed at the bottom of each cage to enable the feces and feed of each individual unit to be collected without urine retention.

The digestibility assay involved an experimental period of four days in order to control the consumption and collection of hard stools. During these days, the feces were collected in the morning, and the hair was removed. The samples were then stored at $-10^{\circ} \mathrm{C}$ until the end of the collection. Subsequently, the feces were sent to the Laboratory of Animal Nutrition of the Department of Zootechnics of UFMG, where the samples were chilled, homogenized, weighed, and dried in a forced ventilation oven at $55^{\circ} \mathrm{C}$ for $72 \mathrm{~h}$ in order to promote predrying. The weights of the air-dried samples were determined. 
The experimental design was completely randomized, with two treatments and 10 animals per treatment, and each experimental unit was composed of one agouti.

\section{Laboratory analyses}

The analyses were performed at the Laboratory of Animal Nutrition of the Department of Zootechnics at the Veterinary School of UFMG. The samples were prepared, and the chemical analyses were conducted according to the methodology proposed by the European Group on Rabbit Nutrition (EGRAN, 1999).

The feces and diets were analyzed for dry matter (DM), crude protein (CP), mineral matter (MM), gross energy (GE), ethereal extract (EE), fiber in neutral detergent (NDF), $\mathrm{Ca}, \mathrm{P}$, and fiber in acidic detergent (ADF), with this last analysis being performed only on the feed and torula samples.

\section{Calculation methods}

The mean daily consumption (MDC) was determined by weighing the leftovers at the beginning and end of the assay and subtracting their weights from the amount provided.

After analyzing the feces, the digestibility coefficients (DC) of the nutrients in the diets were analyzed to determine the apparent digestibility values of the diets containing the different amounts of torula. The DCs were calculated for DM (DCDM), GE (DCGE), MM (DCMM), CP (DCCP), EE (DCEE), and NDF (DCNDF) with the equation proposed by Schneider and Flatt (1975). The values for the digestible energy (DE) and digestible protein (DP) of torula were estimated according to the methodology of Matterson et al. (1965) for $15 \%$ torula and the correction of DM in the diets that was proposed by Villamide (1995). Similarly, the DE and DP values were estimated with linear regressions.

\section{Statistical analyses}

The results that were obtained from the digestibility assays of the rabbits were analyzed with analyses of variance and regression analyses (rabbit assay) with a General Linear Model (GLM) (SAS, 1999), and Tukey's test with a 5\% probability level was used to compare the means.

The results that were obtained from the digestibility assays of the agoutis were examined with analyses of variance with a GLM (SAS, 1999), and the F test was used to compare the relevant means (SNEDECOR; COCHRAN, 1980) with a $5 \%$ probability level.

\section{Results and Discussion}

The results that were obtained for the MDC and apparent DCs of the experimental diets that were offered to the rabbits are presented in Table 7. The substitution did not significantly affect $(\mathrm{P}>0.05)$ any of the DCs examined, which indicated that a diet with $15 \%$ torula did not affect the digestibility of the nutritive principles in the diets or the MDC. Similarly, these findings suggested that, even for the torula percentage examined, the nutritional values of the nutritive principles did not change significantly, which was consistent with the use of up to $15 \%$ of the product in rabbit diets. 
Table 7. Mean daily consumption (MDC; $g$ animal ${ }^{-1}$ ) and apparent digestibility coefficients (DC; \%) of dry matter (DCDM), crude protein (DCCP), fiber in neutral detergent (DCFND), ethereal extract (DCEE), and gross energy (DCGE) in diets for growing rabbits.

\begin{tabular}{lcccccc}
\hline \multicolumn{1}{c}{ Treatment } & MDC & DCDM $^{1}$ & DCCP $^{2}$ & DCFND $^{3}$ & DCEE $^{4}$ & DCGE $^{5}$ \\
\hline $0 \%$ & 113.98 & 71.04 & 80.17 & 66.85 & 77.83 & 71.04 \\
$5 \%$ & 113.96 & 69.98 & 79.55 & 65.50 & 76.46 & 69.98 \\
$10 \%$ & 113.22 & 67.79 & 75.10 & 63.31 & 78.36 & 68.37 \\
$15 \%$ & 115.07 & 74.08 & 78.47 & 70.12 & 82.07 & 73.82 \\
Mean & 114.06 & 70.73 & 78.32 & 66.45 & 78.91 & 70.80 \\
CV $(\%)$ & 14.18 & 6.54 & 4.98 & 12.84 & 8.20 & 6.79 \\
\hline
\end{tabular}

$\mathrm{CV}=$ coefficient of variation

There was no significant effect (Tukey's test; $\mathrm{P}>0.05$ ).

${ }^{1} \mathrm{Y}=71.5214-0.9632 \mathrm{X}+0.0735 \mathrm{X}^{2} . \mathrm{R}^{2}=77.51 \%$

${ }^{2} \mathrm{Y}=80.7663-0.7913 \mathrm{X}+0.0400 \mathrm{X}^{2} \cdot \mathrm{R}^{2}=55.81 \%$

${ }^{3} \mathrm{Y}=67.3442-1.0719 \mathrm{X}+0.0816 \mathrm{X}^{2} \cdot \mathrm{R}^{2}=80.08 \%$

${ }^{4} \mathrm{Y}=78.6455-0.6660 \mathrm{X}+0.0601 \mathrm{X}^{2} . \mathrm{R}^{2}=98.22 \%$

${ }^{5} \mathrm{Y}=71.4240-0.8429 \mathrm{X}+0.0651 \mathrm{X}^{2} \cdot \mathrm{R}^{2}=81.65 \%$

Where $\mathrm{Y}=\mathrm{DC}$ of the nutritive principle and $\mathrm{X}=$ inclusion level of torula.

Chaudhary et al. (1995) assessed the effects of the addition of Saccharomyces cerevisae yeast on the DCs of nutrients in the experimental diets of rabbits, and no statistical differences were found $(\mathrm{P}>$ 0.05 ) for any of the assessed parameters, which was consistent with the findings of this study. Coelho et al. (2008a) assessed the DCDM and DCCP of five diets containing different amounts of torula yeast (Candida utilis) (control, 5\%, 10\%, 15\%, or 20\%) in 40 New Zealand white rabbits, and they found no significant differences $(\mathrm{P}>0.05)$ for DCDM, which was consistent with the present data. For the DCCP, Coelho et al. observed that the DC was significantly lower $(\mathrm{P}<0.05)$ in a diet containing $20 \%$ torula yeast compared with the BD. Intermediate values were obtained in the diets containing $10 \%$ and $15 \%$ torula, and these values were statistically similar to the highest values that were found for the control diet and the diet containing 5\% torula. The mean $\operatorname{DCDM}(58.02 \%)$ and DCCP (73.44\%) values found in that study (COELHO et al., 2008a) were lower than those obtained in this experiment.

Euler et al. (2008) nutritionally assessed torula yeast in rabbit feed and concluded that a diet containing $5 \%$ torula yeast resulted in significantly greater $(\mathrm{P}<0.05) \mathrm{DCs}$ for DM, CP, and GE. They verified that there was a gradual reduction in the DCs in diets containing higher percentages of torula, which differs from the results obtained in this study. The values found in that study for DCDM (71.87\%), DCCP (67.74\%), and DCGE (63.13\%) for a diet containing $5 \%$ torula were lower than those obtained in our experiment for diets with all torula percentages. We understand that variations in the composition of torula can cause different digestive behaviors. The variations in the composition of torula yeast, according to researchers, depends on a series of factors, including the nature of the byproduct used, degree of aeration of the medium, species of yeast, treatment of the culture medium, concentration of salts and buffers that enhance the fermentation process, and the processes used to improve the products, such as drying (BAPTISTA, 2001).

After determining the values for DCGE and DCCP and the amounts of GE and CP in the diets, it was possible to determine the values of the digestible energy (DE) and digestible protein (DP) of the four treatments, which are shown in Table 8. 
Table 8. Values obtained for DP and DE in experimental diets for growing rabbits.

\begin{tabular}{lcccc}
\hline \multirow{2}{*}{ Nutritive principles } & \multicolumn{4}{c}{ Inclusion levels of torula (\%) } \\
\cline { 2 - 5 } & 0 & 5 & 10 & 15 \\
\hline $\mathrm{DM}, \%$ & 89.71 & 90.02 & 89.11 & 89.71 \\
$\mathrm{DP}, \mathrm{g} \mathrm{kg}^{-1} \mathrm{DM}^{-1}$ & 149.3 & 148.3 & 131.6 & 143.3 \\
$\mathrm{DE}, \mathrm{kcal} \mathrm{kg}^{-1} \mathrm{DM}^{-1}$ & $2,861.34$ & $2,833.37$ & $2,760.72$ & $2,999.02$ \\
\hline
\end{tabular}

Arruda et al. (2003b) studied the digestibility of the protein and energy in pelleted feed containing different levels of starch and fiber sources (alfalfa hay or soybean hulls) in growing rabbits, and they found lower DP (11.65\%) and DE $(2,674.0$ $\mathrm{kcal} \mathrm{kg}^{-1}$ ) values than those in our experiment. According to Arruda et al. (2003a), the quality and quantity of dietary fiber can influence the speed of digestion, which indicates that fibrous foods with low lignification of the cell wall and a greater proportion of cellulose, hemicellulose, or pectin should be avoided due to the potential for fatal diarrhea.

Ferreira et al. (2010) assessed the nutrition of semisimplified diets with and without the addition of vinasse in growing rabbits, and they calculated a mean DE value of $2,254.14 \mathrm{kcal} \mathrm{kg}^{-1}$, which was lower than the result determined in this experiment, and the DP equaled $15.47 \%$, which was higher than the mean value obtained in this study. It is worth mentioning that all four diets that were used in that study contained an average of $29.12 \%$ of soybean meal. The results they obtained for the apparent DCs were not influenced by the quality of the hay or vinasse, except for the MM.

When experimenting on animals, it is important to identify and reduce the experimental errors that accumulate during the research as much as possible, because, even if the errors are small, they may cause a significant loss of accuracy when they are totaled. One of the errors that was identified was in the calculation of DP and DE of the tested food diet.

When assessing the torula, the correction of DM that was proposed by Villamide (1995) was applicable to the methodology proposed by Matterson et al. (1965) for the estimation of DE and DP because torula has a lower DM $(85.88 \%)$ than the DM of the BD $(89.71 \%)$. Thus, the greater percentage of torula that was contained in the $\mathrm{BD}$ that was used for this calculation changed from $15 \%$ to $14.42 \%$ when the correction described above was applied. The regression equations that were performed for the nutritive principles of the experimental diets are presented in Table 7. The estimated DE and DP values of torula that were determined with all of the calculation methods are shown in Table 9.

Table 9. DP and DE values for torula that were calculated by three methodologies for growing rabbits.

\begin{tabular}{lccc}
\hline & Matterson et al. (1965) & Villamide (1995) & Linear Regression \\
\hline $\mathrm{DP}, \mathrm{g} \mathrm{kg}^{-1} \mathrm{DM}^{-1}$ & 182.6 & 190.9 & 293.0 \\
$\mathrm{DE}, \mathrm{kcal} \mathrm{kg}^{-1} \mathrm{DM}^{-1}$ & $2,870.52$ & $2,870.89$ & $2,805.22$ \\
\hline
\end{tabular}

Faria et al. (2000) have examined the nutritive value of recovery yeast (Saccharomyces sp.) that were dried with a rotating roller or by Spray-Dry in rabbits, and they found DP values that were equal 
to $18.25 \%$ and $25.22 \%$, respectively, and $\mathrm{DE}$ values $\left(\mathrm{kcal} \mathrm{kg}^{-1} \mathrm{DM}^{-1}\right.$ ) that were equal to $3,248.0$ and 3,859.0, respectively. Therefore, the DP of yeast that was dried by a rotating roller was similar to the results that were obtained in this study because a similar technology was used. However, this was not found for the DP of yeast that was obtained with Spray-Dry or for the DE that was obtained with both methods. The variations in the nutritive values of yeast depend on the original species and the technologies that were used to obtain the yeast.

The results that were obtained for the MDC and DCs in the experiment on the agoutis are presented in Table 10. Because vinasse torula has a low EE, a reduction was observed in the amount of this nutritive principle in the torula diet. It is worth mentioning that the $\mathrm{P}$ content decreased, which may suggest that a correction of this element is required when the percentage of torula that is included in the diets is $30 \%$.

Table 10. Mean daily consumption (MDC; $\mathrm{g}_{\text {animal }}{ }^{-1}$ ) and apparent digestibility coefficients (DCs \%) of dry matter (DCDM), crude protein (DCCP), fiber in neutral detergent (DCFND), mineral matter (DCMM), organic matter (DCOM), ethereal extract (DCEE), and gross energy (DCGE) of feed for mature agoutis.

\begin{tabular}{lcccccccc}
\hline & MDC & DCDM & DCCP & CDFND & DCMM & DCOM & DCEE & DCGE \\
\hline BD & 84.48 & 67.62 & 71.12 & 72.70 & 36.27 & 70.52 & $63.39 \mathrm{a}$ & $68.00 \mathrm{a}$ \\
TD & 90.48 & 67.06 & 68.19 & 69.89 & 33.16 & 70.27 & $48.04 \mathrm{~b}$ & $63.73 \mathrm{~b}$ \\
CV $(\%)$ & 17.84 & 3.77 & 6.45 & 8.86 & 15.90 & 3.28 & 26.34 & 5.91 \\
\hline
\end{tabular}

The means followed by different letters in the same column significantly differ ( $\mathrm{F}$ test; $\mathrm{P}<0.05)$.

The results revealed that the addition of torula to the diet did not influence $(\mathrm{P}>0.05)$ the nutritive parameters that were assessed, except for DCEE and DCGE $(\mathrm{P}<0.05)$. This may have occurred because the coefficients are interlinked because the lipids that are contained in the EE are a source of energy and a decrease in DCEE causes a subsequent decrease in DCGE. One hypothesis for this lower energy use is that the agouti is an animal that lives in the woods and forests and that frequently feeds on fruits and tubers, which are foods that exhibit higher energy availabilities in the forms of sugars and starch, respectively. Another possible explanation could be its reduced capacity to digest the energy that is contained in cereals and grains, such as in the pelleted feed that was used in this study.

The DCOM was greater than the DCDM in this study. Torula and yeasts generally have a high content of $\mathrm{OM}$, and some components of this fraction are still unknown or have been rarely studied. One of the limitations of high percentages of substitution with torula is expected to be due to the digestibility of $\mathrm{OM}$ and enzymatic limitations. Therefore, to assess the digestibility of $\mathrm{OM}$ when the substitution index was 30\%, the CDOM was determined in this experiment. No significant reduction was found in the statistical analysis $(\mathrm{P}>0.05)$, which suggested that the diet containing $30 \%$ torula did not affect the digestibility of the organic fraction of the diet.

The results in this study can only be compared with data that were obtained from other domestic species because no studies in the literature have examined the digestibility of diets that contain this product in agoutis or other wild species.

Chaudhary et al. (1995) assessed the effects of administering yeast (Saccharomyces cerevisae) to rabbits, and Luick et al. (1992) evaluated diets that were supplemented with yeast (Lacto sacc). Both assessed the DCs of nutrients in the experimental diets, and no statistically significant differences were found $(\mathrm{P}>0.05)$ for the parameters assessed, which differed from our study that found significant 
differences in DCEE and DCGE.

The addition of microbial protein to diets at a percentage of $30 \%$, which is considered high, may influence the digestibility of other nutrients, including protein. Even for growing animals that require less $\mathrm{CP}$ than the high content of $\mathrm{CP}$ that was analyzed in the feed containing torula, the DCCP was not significant $(\mathrm{P}>0.05)$, indicating that the inclusion of $30 \%$ did not preclude the use of protein in the diet. We can infer that percentages of torula yeast up to $30 \%$ can be added to diets without affecting the nutritional value of the diet of a growing agouti.

Ferreira et al. (2010) nutritionally assessed semisimplified diets with and without added vinasse in growing rabbits and found that the average DCDM (44.14\%), DCGE (47.44\%), and DCFND (16.29\%) that they found were lower than the values found in this experiment. Moreover, the DCMM (51.15\%), DCCP (75.46\%), MDC (122.03 $\mathrm{g}$ animal $\left.^{-1}\right)$, and DP in the diet $(15.47 \%)$ that they found were higher than the mean values obtained in this study. It is worth noting that all four diets that were used in that study contained an average of $29.12 \%$ of soybean meal, which suggests that the diets that contained torula in this study were equivalent to those used in that study.

Compared with the digestibility assay that was performed in rabbits in this study, higher DC values were obtained in the agoutis, but the results were similar in this experiment. It is reasonable to predict that New Zealand rabbits, which have already been selected and domesticated by animal breeding programs, would be able to take better advantage of the available nutrients than wild rodents. However, the similar values between the two groups demonstrate the efficiency of agoutis, which, despite still being in the early stages of domestication and adaptation to captivity, confirms their high zootechnic potential. In the experiment on rabbits, it is worth highlighting that these animals were still growing, whereas the agoutis were not, as they were all breeding adults. Growing animals have better digestive capacities than breeding animals do.

By determining the DCGE and DCCP values and the amounts of $\mathrm{GE}$ and $\mathrm{CP}$ in the diets in this study, it was possible to calculate the DE and DP values in both treatments, and the results are presented in Table 11. When assessing torula, the differences in DE and DP values that were obtained with the formulae of Matterson et al. (1965) and Villamide (1995) were expressed in the percentages of the added torula because $30 \%$ was the value used by Matterson et al. (1965). In the formula of Villamide (1995), the DM that refers to the test food is corrected when compared to the BD because the torula has a lower DM content than that in the BD $(90.34 \%)$. The results that were obtained with the two procedures are shown in Table 12.

Table 11. Values obtained for DE and DP in diets used for agoutis.

\begin{tabular}{lcc}
\hline \multirow{2}{*}{ Nutritive Principle } & \multicolumn{2}{c}{ Experimental diets } \\
\cline { 2 - 3 } & BD & TD \\
\hline $\mathrm{DM}, \%$ & 90.34 & 88.97 \\
$\mathrm{DP}, \mathrm{g} \mathrm{kg}^{-1} \mathrm{DM}^{-1}$ & 131.4 & 159.7 \\
$\mathrm{DE}, \mathrm{kcal} \mathrm{kg}^{-1} \mathrm{DM}^{-1}$ & $2,807.22$ & $2,392.80$ \\
\hline
\end{tabular}

Table 12. DP and DE values of the test diet that were calculated with the two methodologies for mature agoutis.

\begin{tabular}{lcc}
\hline & Matterson et al. (1965) & Villamide (1995) \\
\hline $\mathrm{DP}, \mathrm{g} \mathrm{kg}^{-1} \mathrm{DM}^{-1}$ & 259.1 & 263.1 \\
$\mathrm{DE}, \mathrm{kcal} \mathrm{kg}^{-1} \mathrm{DM}^{-1}$ & $1,714.22$ & $1,663.69$ \\
\hline
\end{tabular}


The results showed that the calculation procedure of Villamide (1995) differed from that of Matterson et al. (1965). Therefore, both were used in order to show the differences between them. It is worth noting that the corrected formula of Villamide (1995) was more appropriate in some circumstances, with the need to correct the value from $30 \%$ to $28.95 \%$.

No previous data on the DE and DP values for torula in agoutis were found, and this prevents a direct comparison of the values obtained in this study with those obtained in other studies. The DE value $\left(1,663.69 \mathrm{kcal} \mathrm{kg}^{-1} \mathrm{DM}^{-1}\right)$ that was obtained showed that the inclusion of $30 \%$ torula provided low energy that can be used by growing agoutis compared with the results obtained for $\mathrm{DE}$ for the rabbits in this study. The DP value showed that the inclusion of $30 \%$ torula provided a high amount of protein that can be used by growing agoutis.

Moreover, the efficiency of the digestion of the EE changed $(\mathrm{P}<0.05)$, although it did not alter the consumption $(\mathrm{P}>0.05)$. This factor may also have influenced the results that were related to the decrease in DCGE in the diets with added torula.

Another factor that needs to be considered is the possibility that the inclusion of $30 \%$ yeast may have altered the intestinal microbiota and the fermentation pattern, and these possibilities need to be specifically studied. Several species of bacteria have been found in the intestines, mainly in the cecum and large intestine, of agoutis, and this suggests high microbial activity in these locations (MCBEE, 1971). This has also been observed in the cecum and large intestine of horses (CUNNINGHAM, 1993), which indicates a direct relationship with the feeding habits of this animal, which ingests seeds and fruits (SILVIUS; FRAGOSO, 2003; LOPES et al., 2004), in addition to native plants, vegetables, and legumes (LOPES et al., 2004). The diet of agoutis in nature is composed of food that is low in protein, and it is possible that, when these animals are faced with a considerably high amount of a protein source, such as torula, the animal improves its natural efficiency compared with its ability to use digestible protein.

In this experiment on agoutis, the results may have been a consequence of food processing because the BD was milled and repelleted to create treatment 2. This mechanical and thermal biprocessing that was performed on treatment 2 may have affected the availability of EE and energy, thus explaining the decrease in both of the digestibilities of EE and energy in the diet with torula.

The use of the adaptation and maintenance protocol for caged animals was useful for assessing the changes that occur to the breeding system in animals in captivity because the animals in these conditions show passive behavior and do not die before old age. No cases of diarrhea were observed. Therefore, the adaptation protocol for agoutis was effective.

\section{Conclusions}

Under the conditions in this study, we can conclude that the inclusion levels that were tested for torula yeast did not interfere with the DCs that were studied or with the MDC of New Zealand white rabbits and that up to $15 \%$ of torula can be added to pelleted diets without altering the digestibility of the nutritive principles. The estimated values for the $\mathrm{DE}\left(\mathrm{kcal} \mathrm{kg}^{-1} \mathrm{DM}^{-1}\right)$ of torula were $2,870.52$ with the methodology of Matterson et al. (1965), 2,870.89 with the correction proposed by Villamide (1995), and 2,805.22 when calculated by regression. The estimated DP values $\left(\mathrm{g} \mathrm{kg}^{-1} \mathrm{DM}^{-1}\right)$ for torula were 182.6 with the methodology of Matterson et al. (1965) and 190.9 with the correction of Villamide (1995). The DP value $\left(\mathrm{g} \mathrm{kg}^{-1} \mathrm{DM}^{-1}\right)$ that was estimated by linear regression was 293.0.

For the agoutis, we can conclude that the inclusion of $30 \%$ torula yeast in their diet did not interfere with DCDM, DCCP, DCFND, DCOM, or MDC, but it reduced DCEE and DCGE, which suggests that torula diminished $(\mathrm{P}<0.05)$ energy use. However, further studies are required to better 
understand this effect on this species. The estimated DE values $\left(\mathrm{kcal} \mathrm{kg}^{-1} \mathrm{DM}^{-1}\right)$ of torula were $1,714.22$ when the methodology of Matterson et al. (1965) was used and 1,663.69 with that of Villamide (1995). The estimated DP values $\left(\mathrm{g} \mathrm{kg}^{-1} \mathrm{DM}^{-1}\right)$ of torula were 259.1 with the methodology of Matterson et al. (1965) and 263.2 with that of Villamide (1995).

\section{Acknowledgments}

To CNPq, CAPES, and FAPEMIG for the financial support and grants awarded and to the Federal University of Minas Gerais.

\section{References}

ARRUDA, A. M. V.; LOPES, D. C.; FERREIRA, W. M. ROSTAGNO, H. S.; QUEIROZ, A. C.; PEREIRA, E. S.; FERREIRA, A. S.; SILVA, J. F. Desempenho e características de carcaça de coelhos alimentados com rações contendo diferentes níveis de amido e fontes de fibra. Revista da Sociedade de Brasileira de Zootecnia, Viçosa, v. 32, n. 6, p. 1311-1320, 2003 b.

ARRUDA, A. M. V.; PEREIRA, E. S.; MIZUBUT, I. Y.; LOPES, D. C.; SILVA, J. F. Digestibilidade de nutrientes em coelhos alimentados com rami (Bohemeria nivea). Semina: Ciências Agrárias, Londrina, v. 26, n. 4, p. 581590, 2005

ARRUDA, A. M. V.; PEREIRA, E. S.; MIZUBUT, I. Y.; SILVA, L. D. F. Importância da fibra na nutrição de coelhos. Semina: Ciências Agrárias, Londrina, v. 24, n. 1, p. 181-190, 2003a.

BAPTISTA, A. S. Saccharomyces cerevisae em milho armazenamento e o efeito na redução da aflatoxicose. 2001. Dissertação (Mestrado em Microbiologia Agrícola) - Escola Superior de Agricultura Luiz de Queiroz, Universidade de São Paulo, Piracicaba.

BUTOLO, J. E. Qualidade de ingredientes na alimentação animal. Campinas: CBNA, 2002. 430 p.

CHAUDHARY, L. C.; SINGH, R.; KAMRA, D. N.; PATHAK, N. N. Effect of oral administration of yeast (Saccharomyces cerevisiae) on digestibility and growth performance of rabbits fed diets of different fibre content. World Rabbit Science, Valência, v. 3, n. 1, p. 15-18, 1995.

COELHO, C. C. G. M.; EULER, A. C.; FERREIRA, W. M.; TEIXEIRA, E.; CUTTIS, L. E. D.; PERDIGÓN, P. L.; OLIVEIRA, C. E. A. Coeficiente de digestibilidade aparente da matéria seca e proteína bruta de dietas com diferentes níveis de inclusão de levedura torula (Candida utilis) para coelhos Nova Zelândia Branco. In: CONGRESSO BRASILEIRO DE ZOOTECNIA, 18., 2008, João Pessoa. Anais... João Pessoa: UFPB/ABZ, 2008a. p. 1-4.

COELHO, C. C. G. M.; EULER, A. C.; FERREIRA, W. M.; TEIXEIRA, E.; CUTTIS, L. E. D.; PERDIGÓN, P. L.; OLIVEIRA, C. E. A. Coeficiente de digestibilidade aparente da energia digestível de dietas com inclusão de levedura torula (Candida utilis) para coelhos Nova Zelândia Branco. In: CONGRESSO BRASILEIRO DE ZOOTECNIA, 18., 2008, João Pessoa. Anais... João Pessoa: UFPB/ABZ, 2008b. p. 1-4.

CUNNINGHAM, J. G. Tratado de fisiologia veterinária. Rio de Janeiro: Guanabara Koogan, 1993. 237 p.

DE BLAS, C.; MATEOS, G. G. Feed formulation: nutrition of the rabbit. $2^{\text {th }}$ ed. Cambridge: CAB International, 2010. $325 \mathrm{p}$.

EULER, A. C. C. Utilização digestiva, metodologias de avaliação "in vitro" de dietas e caracterização da microbiota cecal em coelhos suplementados com Lithothamnium. 2009. Tese (Doutorado em Zootecnia na área de Nutrição Animal) - Escola de Veterinária, Universidade Federal de Minas Gerais, Belo Horizonte.

EULER, A. C.; FERREIRA, W. M.; COELHO, C. C. G. M.; TEIXEIRA, E.; CUTTIS, L. E. D.; FONTES, D. O.; PERDIGÓN, P. L. Avaliação nutricional da levedura torula (Candida utilis) para a alimentação de coelhos. In: CONGRESSO BRASILEIRO DE ZOOTECNIA, 2008, João Pessoa. Anais... João Pessoa: Zootec, 2008. p. 1-4.

EUROPEAN GROUP ON RABBIT NUTRITION EGRAN. Harmonization in rabbit nutrition research: recommendations to analyse some basic chemical components of feeds and faeces. In: WORKSHOP FROM MEETING OF MADRID, 1999, Madrid. Document... Madrid: EGRAN, 1999. 10 p.

FARIA, H. G.; SCAPINELLO, C.; FURLAN, A. C.; MOREIRA, I.; MARTINS, E. N. Valor nutritivo das leveduras de recuperação (Saccharomyces $s p$ ), seca por rolo rotativo ou por "Spray-Dry", para coelhos em crescimento. Revista Brasileira de Zootecnia, Viçosa, MG, v. 29, n. 6, p. 1750-1753, 2000.

FERREIRA, W. M.; COELHO, C. C. G. M.; BAPTISTA, D. M. Avaliação nutricional de dietas semi simplificadas com e sem adição de vinhaça para coelhos em crescimento. In: REUNIÃO ANUAL DA SOCIEDADE BRASILEIRA DE ZOOTECNIA, 47., 2010, Salvador. Anais... Salvador: SBZ, 2010. p. 1-4. 
GARCIA, G. W.; BAPTISTE, Q. S.; ADOGWA, A. O.; KAAKUNI, M.; MAKITA, T. The digestive system of the agouti (Dasyprocta leporina): gross anatomy and histology. Japanese Journal of Zoo and Wildlife Medicine, Tóquio, v. 5, n. 1, p. 55-66, 2000.

LOPES, J. B.; CAVALCANTE, R. R.; ALMEIDA, M. M.; CARVALHO, M. A. M.; MOURA, S. G.; DANTAS FILHO, L. A.; CONCEIÇÃO, W. L. F. Performance of agouti (Dasyprocta prymnolopha) bred in captivity according to sex and parturition in Teresina. Piauí. Revista Brasileira de Zootecnia, Viçosa, MG, v. 33, n. 6, p. 2318-2322, 2004.

LUI, J. F.; CAVALCANTE NETO, A.; FONSECA, C. Conservação e uso de animais silvestres no Brasil. In: CONGRESSO BRASILEIRO DE ZOOTECNIA, 18., 2008, João Pessoa. Anais... João Pessoa: Zootec, 2008. p. $1-4$.

LUICK, V. R.; EL-SAYAAD, G. A.; CHEEKE, P. R. Effect of fructo-oligosaccharides and yeast culture on growth performance of rabbits. Journal Applied of Rabbit Research, Corvallis, v. 15, n. 2, p. 1121-1128, 1992.

MATTERSON, L. D.; POTTER, L. M.; STUTZ, N. W. The metabolizable energy of feed ingredients for chickens. Agricultural Experimental Station Research Report, Stillwater, v. 7, n. 1, p. 3-11, 1965.

MCBEE, R. H. Significance of intestinal microflora in herbivory. Annual Review of Ecology and Systematics, Palo Alto, v. 2, n. 1, p. 165-176, 1971.

NATIONAL RESEARCH COUNCIL - NRC. Nutrient requirements of domestic animals. Nutrient requirements of swine. $8^{\text {th }}$ ed. Washington, D.C.: National Academy of Sciences, 1998. $111 \mathrm{p}$.

NOGUEIRA, P. Mude a sua dieta e salve a Amazônia. Revista Galileu, São Paulo, n. 193, p. 50-55, 2007.

PÉREZ, J. M.; LEBAS, F.; GIDENNE, T.; MAERTENS, L.; XICCATO, G.; PARIGI-BINI, R.; DALLE-ZOTTE, A.; COSSU, M. E.; CARAZZOLO, A.; VILLAMIDE, M. J.; CARABAÑO, R.; FRAGA, M. J.; RAMOS, M. A.; CERVERA, C.; BLAS, E.; FERNANDEZ, J.; FALCÃO-E-CUNHA, L.; BENGALA-FREIRE, J. European reference method for in vivo determination of diet digestibility in rabbits. World Rabbit Science, Valência, v. 3, n. 1, p. 41-43, 1995.
PILOTO, J. L.; MACÍAS, M. Studies on the chemical composition of Cuban torula yeast grown on sugar cane molasses or from vinasse residues. Revista Computadorizada de Producción Porcina, La Habana, v. 12, n. 2, p. 111-115, 2005.

RODRÍGUEZ, B.; MORA, L. M.; EULER, A. C.; OLIVEIRA, D. F.; LEZCANO, P.; LARA, L. Energia metabolizável e digestibilidade da levedura torula (Candida utilis) de vinhaça para as aves. In: LATIN AMERICAN POULTRY CONGRESS, 22., 2011, Buenos Aires. Anais... Buenos Aires: Instituto de Ciência Animal, 2011.p. 1-4.

SAURA, G.; OTERO, M. A.; RAMBLA, J. A.; MARTINEZ-VALDIVIESO, N. G.; PÉREZ, I. Producción de levadura forrajera a partir de vinazas de destilería. In: CONGRESO INTERNACIONAL SOBRE AZÚCAR Y DERIVADOS, 10., 2008, Havana. Anais... La Habana: CLAC, 2008. p. 341.

SCHNEIDER, B. A.; FLATT, W. P. The evaluation of feeds through digestibility experiences. Athens: The University of Georgia, 1975. 423 p.

SILVIUS, K. M.; FRAGOSO, J. M. V. Red-rumped agouti (Dasyprocta leporina): home range use in an amazonian forest: implications for the aggregated distribution of forest trees. Biotropica, Lawrence, v. 35, n. 1, p. 74-83, 2003.

SNEDECOR, G. W; COCHRAN, W. G. Statistical methods. Ames: Iowa State Univ. Press, 1980. 507 p.

STATISTICAL ANALYSIS SYSTEM INSTITUTE SAS. SAS/STAT user's guide. Version 8, Cary, NC: SAS Institute Inc., 1999.

VILLAMIDE, M. J. Methods of energy evaluation of feed ingredients for rabbits and their accuracy. Animal Feed Science Technology, Amsterdam, v. 57, n. 4, p. 211223, 1995. 
